\title{
Management Control in Global Mass Market Retailers
}

\author{
Francesca Gennari ${ }^{*}$
}

\begin{abstract}
For large retail firms, management control is a valid tool with which to face the competition of global markets and to manage corporate complexity. The management control systems of global retailers have specific characteristics that stem from the geographical dispersion of their organisational units and frequently from the existence of cooperative alliances with other companies
\end{abstract}

Keywords: Management Control; Global Competition; Global Retailers; Mass Market Retailers

\section{Global Markets and Management Control}

In recent decades, globalisation has also involved the marketing companies that operate on mass retail markets. Global retailers are generally characterised by product ranges that are able to satisfy increasingly broad and varied consumer demand and by the territorial expansion of their sales network.

On global markets, where traditional space-time barriers are instable, and competition space is constantly being redefined, strongly competition-oriented logics are establishing themselves, in which time and the ability to anticipate one's rivals are the main critical success factors (market-space and time-based competition) ${ }^{1}$. Retailers who intend to maintain or improve their performance on these markets, often find themselves having to deal with problems related to their increasing complexity, in terms of both the composition of the product/market combination (strategic complexity) and their organisational structure (organisational complexity). In fact, the levels of complexity identified must also be assessed from a broader viewpoint, i.e. one that does not only take the individual company into account but also considers the relations established with other companies (commercial and/or industrial). From a global perspective, processes to produce commercial services may involve companies/groups of companies in which the individual structures maintain their importance, although shared transverse processes also acquire significance.

\footnotetext{
* Assistant Professor of Business Administration, University of Brescia (fgennari@eco.unibs.it) 
In order to deal with situations of growing complexity, companies express the need to acquire tools which, by helping to clearly guide a company towards its goals, emerge as a significant support to corporate governance, while they respect value creation and minimise risk ${ }^{2}$. Management control is a collection of structures and processes designed to facilitate the implementation of top management decisions in the organisation, through the performance of activities and the related verification of the results achieved.

The creation of an effective management control system becomes all the more necessary for global companies that have geographically dispersed organisational units (often separated by significant physical and cultural distances) but centralised top corporate governance organs, which are responsible for outlining the strategic guidelines that are valid for the entire organisation ${ }^{3}$. On one hand the control mechanisms convey the strategic guidelines to the units responsible for their organisation and, on the other, they guarantee feedback to the management organs regarding the results achieved.

On the basis of these considerations, this article intends to analyse the specific nature of the components of the management control system, with reference to global retailers that operate on mass markets. Our analysis will focus in particular on the problem of defining the degree of corporate complexity, an indispensable step before any control mechanism can be implemented correctly. On the basis of the degree of complexity identified, we will specify the optimal characteristics for both the structural aspects of management control (organisational structure and information system) and the more specifically procedural aspects (process).

\section{Mass Market Retailers and Corporate Complexity}

Global markets where traditional competition boundaries are instable, force retail companies to constantly verify their choices in terms of:

- strategic complexity, i.e. the global composition of supply (in terms of products/services and market served) and its consistency with purchasing expectations;

- organisational complexity regarding: relations between ownership and management; the existing organisational structure (in terms of the delegation of responsibility and the contributions demanded of the company's various operating units) and binding agreements with other companies.

Factors of complexity tend to influence each other in response to the company's need to adapt to or anticipate a contextual situation: expanding the products offered on the global markets necessarily demands organisational changes. Similarly, the decision to share part of the commercial processes with other companies can have strategic implications with regard to the markets served.

By combining the variables that generate global corporate complexity, it is possible to identify three basic levels of complexity: low, medium and high. In retail companies with a low level of complexity, there is a substantial overlapping of roles between owners, administrators and organisation, and one area of business, which is 
limited to the local context. These companies do not generally show any need for advanced control systems to support management.

Global mass market retailers, on the other hand, tend to have a medium or high level of complexity. Medium complexity companies reflect a clear differentiation of the decision-making organs inside the corporate structure and more significant processes to delegate responsibility, primarily induced by the expansion of the markets served. The strategy pursued in terms of the market served may be a qualifying element in decisions regarding the maintenance of a position of independence rather than the creation of forms of legal, operational or contractual integration ${ }^{4}$ and these situations demand the creation of macro-organisations with a higher level of strategic-organisational complexity.

The highest level of complexity is linked to structures founded on cooperative alliances (networks). Networks are extremely ramified organisations because of the relationships that develop between participants, but at the same time they are flexible and dynamic because they are strongly market-oriented. In networks of companies operating on global markets, traditional models of competition between retail companies are backed up by competition systems between channels, which can also involve industrial companies. In these macro-organisations, new demands for governance and control take hold, to guarantee correct and responsible behaviour by all company operators, with the goal of meeting the expectations of increasingly broad categories of stakeholders, according to criteria of equity and transparency ${ }^{5}$.

It is therefore essential to analyse a company's degree of complexity in order to organise the structural and procedural aspects of the management control system correctly.

\section{Global Retailers and Structural Components of Management Control}

The structural components of management control stem from the organisational structure and control system information.

The organisational control structure defines the responsibilities of the company's various organisational units, by defining the type and entity of the resources that each unit may employ in the performance of its duties, in relation to the targets assigned to it. This breaks the existing organisation down into responsibility centres, which are attributed specific governance roles and expected to contribute functionally to achieve the company's strategic objectives.

The organisational control system of global retailers must first consider whether there are any existing integrated relationships or cooperative alliances with other companies. The more these relationships are based on shared corporate risk, the more stable and durable they are, and they can significantly influence the attribution of strategic and managerial responsibilities.

The time-based competition typical of global markets suggests that it is worth taking advantage of organisational structures that effectively delegate power but are also flexible, in other words, able to adapt rapidly and inexpensively to changes in the appropriate context. This results in an emphasis on decentralised decision-making by units dislocated around the territory ${ }^{6}$ and a reassessment of matrix-based organisational structures ${ }^{7}$. The latter seem to adapt most successfully to continuing 
changes in competitive boundaries, taking into consideration the fact that, alongside permanent responsibility centres (for example, purchasing department, sales department, etc.) temporary centres may also develop (for example logistics manager, retail manager, etc.), with powers cutting across the organisation, and responsibility for managing critical economic levers when specific situations arise.

'METRO GROUP aims to improve its process efficiency to be able to tap existing and new markets even better. This is why Shape 2012 employs the maxim: as decentrally as possible, as centrally as necessary. Shape 2010 will markedly reduce the Group's complexity. The new organization is characterized by progressive structures with full operational responsibility at the level of the sales divisions. This facilitates greater customer orientation, improved cost management and gains in efficiency. The sales divisions are given the entrepreneurial freedom they need to meet the centrally defined strategic goals and return targets'(www.metrogroup.de, last update 19 October 2010).

Control system information has to support all decision-making processes by collecting and processing the information used by corporate governance organs and organisation. We can rightly claim that retail companies have based their development - and their relations with customers/consumers and with industrial companies - on their ability to govern information flows, creating a virtual channel of information in parallel to the physical channel of goods. This concept is strengthened on rapidly evolving markets where a company's success depends on its ability to govern this dynamism, at least in part.

Information technology, which is now widespread, cuts data collection costs enormously, and has made a huge amount of information available, but it poses problems related to its selection. For global companies, decision-making times and subsequent actions must be extremely short: the bottom-up information flow usually has to be managed in real time, by channelling the data arriving from the many company units in a single organisation or network, into a single information platform.

'Information technology is a success factor for Autogrill and a great opportunity for development in all the Company's operating activities. [...] Over ten thousand check-outs across four continents, around 1.5 million receipts issued everyday - this is just the basis of a system that enables us to analyze and anticipate customers' needs from day to day - . [...] In the meantime, projects are continually underway to develop common applications platforms to upgrade management of key Group processes. In particular, the European associates have launched a plan to extend the common IT system for managing business functions in branches and points of sale (administration, performance management reporting, $f \& b$ and supply chain.[...]' (www.autogrill.com, last update 21 July 2009). 
Any opportunities for competitive advantage are therefore linked to the ability to select relevant data and process them, on each occasion, according to prevailing information priorities. In the past most problems regarded the ways data were collected; today the systematic selection of the significant data and the activation of a top-down feedback flow to support daily management processes (changes to the prices of products being promoted, replacement of a shelf brand, design of promotional leaflets, etc.) appears more critical. The effectiveness of the control system information can therefore encourage the implementation of time-based strategies, based on the ability to act before competitors, by constantly adapting supply.

The result is that the correct planning of the information control system should simultaneously consider the corporate complexity on one hand and the reference timeframe on the other. The organisation of objectives and the measurement/collection of the results that must reflect the breakdown of the organisational structure into responsibility centres, and the division of the company's global activities into significant business areas, both derive from this complexity. The timely structure of the information is linked primarily to significant moments in the control process (forecast values and actual values) and to the frequency with which information is prepared.

In low-complexity retail companies, decision-making processes are sufficiently supported by the traditional accounting system, which is designed to record trade with other economic entities. On the other hand, companies with a high degree of complexity, like global retailers, which repeatedly reveal a need for information, also need a better structured management accounting information system. On a recurrent and systematic level (not only final results but also forecasts) this can provide both global economic measurements for the entire company, and partial economic measurements, referred to items of observation that are deemed significant.

The implementation of formal control systems should therefore guarantee the programming and a level of detail of the information that is consistent with governance requirements and the need to link the organisational units that make up the company or the network.

\section{Global Retailers and Procedural Components of Management Control}

The correct configuration of the organisational structure and control system information emerges as a condition for an effective control process. The latter defines the manner and frequency of activities to define objectives (long-term and short-term planning) and to observe results, on the basis of the company's degree of complexity, as well as the dynamism of the outside world.

It is crucial to correctly translate corporate strategies into managerial targets, particularly for global companies, which usually have a single strategic management body and fragmented operating units. In these hypotheses, the concept of 'glocalisation' seems to be acquiring particular importance. It was coined to define supply systems that respond to global strategies but also change to adapt the product to the needs of specific local contexts. In other words, the definition of global strategic guidelines must be suitably translated into managerial objectives that respect 
the decisional-making and operational autonomy of the units disseminated through the territory.

\author{
$\square$ 'If you come to China with preconceived ideas after having been \\ successful in Europe or in the United States, you make mistake after \\ mistake'. Jean-Loc Chéreau, President of Carrefour China (interviewed \\ by McKinsey, 2006)
}

The geographical dispersion of the organisational units draws attention to the problem of enhancing the unitary character of the company while also guaranteeing the necessary flexibility to adapt governance and control processes to the characteristics of the local socio-geographic and competitive context ${ }^{8}$. The current trend can be attributed to both the centralisation of methodological processes in the parent company, and to the strategic importance of control processes (medium and long-term planning, the design of the information platform, the definition of general policies to advance human resources, risk mapping, outlining of global internal auditing plans, etc.) with the operating units responsible for the implementation stage and for monitoring actions (the performance indices and monitoring of results, the introduction of user-friendly IT tools, the definition of personnel assessment systems, monitoring of exposure to the risks identified, specific checks to control the activities performed, etc.).

As a result, in global companies, the effectiveness of the management control system is clearly reflected in the cultural and communicational aspects consolidated in the context of the organisation, and this results in the adoption of common languages, mechanisms and tools that can foster shared knowledge and managerial alignment between geographically distant individuals and structures.

Moreover, the control process must not overlook the changes taking place in traditional competition levers. On one hand, sudden changes in the key success factors impose a reduction in observation times, the intensification of the control communications and development that reflects different economic scenarios, for example reflecting the most rational management development hypothesis, and a disaster case hypothesis.

On the other hand, corporate intangible assets play an increasingly important role, i.e. those variables of success which, for their very intangibility, escape easy identification and direct quantification, although they play a leading role in the achievement of company performance. Obviously, monitoring intangible assets does not replace traditional control variables, but supplements them with elements correlated to the growth of the intangible value of the company.

Modern management control systems should therefore elaborate both new processes to translate intangible key success factors into performance indicators to guide the activities of the responsibility centres, and new report models that highlight the contribution to competitive economic and social corporate performances ${ }^{9}$.

And finally, the management control processes of global companies must be designed and implemented by carefully studying possible moments of contact or potential overlapping with tools typical of other controls undertaken inside the company (for example internal auditing, risk management, etc.). In other words it is necessary to adopt a systemic, integrated view with regard to all the controls that are 
developed in a complex company and which, although differentiated by the subject, targets and object of intervention, are usually oriented to achieving maximum effectiveness and efficiency of operating activities, minimising risk, respecting standards and evolving reliable information flows ${ }^{10}$.

\section{Bibliography}

Alexander Nicholas, Doherty Anne M., Carpenter Jason M., Moore Marguerite, Consumer Receptiveness to International Retail Market Entry, International Journal of Retail \& Distribution Management, vol. 38, n. 3, 2010. http://dx.doi.org/10.1108/09590551011027104

Anthony Robert N, Govindarajan Vijay, Management Control Systems, McGraw-Hill IRWIN, Chicago, 2007.

Applegate Lynda M., Austin Robert D., McFarlan Warren F., Creating Business Advantage in the Information Age, McGraw-Hill, Boston, 2002.

Best Roger J., Market-Based Management. Strategies for Growing Customer Value and Profitability, Prentice Hall, New Jersey, 2008.

Brondoni Silvio M., Market Driven Management, Competitive Space and Global Networks, Symphonya. Emerging Issues in Management (symphonya.unimib.it), n. 1, 2008. http://dx.doi.org/10.4468/2008.1.02brondoni

Brondoni Silvio M., Market Driven Management, Competitive Customer Value and Global Networks, Symphonya. Emerging Issues in Management (symphonya.unimib.it), n. 1, 2009. http://dx.doi.org/10.4468/2009.1.02brondoni

Campbell Dennis, Datar Srikant M., Sandino Tatiana, Organizational Design and Control Across Multiple Markets: the Case of Franchising in the Convenience Store Industry, The Accounting Review, vol. 84, n. 6, 2009. http://dx.doi.org/10.2308/accr.2009.84.6.1749

Clarke Thomas, Dela Rama Marie, Corporate Governance and Globalization, The Governance of Globalization, vol. 3, Sage Pub., Usa, 2006.

Committee of Sponsoring Organizations, Internal Control. Integrated Framework, Aicpa, Usa, 2002.

Day George S., The Market-Driven Organization, The Free Press, New York, 1999.

Epstein Marc J., Manzoni Jean-François, Davila Antonio, Performance Measurement and Management Control: Innovative Concepts and Practices, Emerald Group Publishing, UK, 2010.

Freeman Edward R., Strategic Management. A Stakeholder Approach, Cambridge University Press, UK, 2010.

Gatignon Hubert, Kimberly John R., Gunther Robert E., Alliance on Globalizing, Cambridge University Press, UK, 2004.

Hitt Michael, Ireland Duane R., Hoskisson Robert E, Rowe Glenn, Sheppard Jerry, Strategic Management: Competitiveness and Globalization, Nelson Education Ltd, Canada, 2009.

Itami Hiroyuki, Roehl Thomas W., Mobilizing Invisible Assets, Softcover University Press, Harvard, 1991.

Kaplan Robert S., Mikes Anette, Simons Robert, Tufano Peter, Hoffmann Michael Jr., Managing Risk in the New World, Harvard Business Review, vol. 87, n. 10, 2009.

Kaplan Robert S., Norton David P., Measuring the Strategic Readiness of Intangible Assets, Harvard Business Review, vol. 82, n. 2, 2004.

Kaplan Robert S., Norton David P., Alignment: Using the Balanced Scorecard to Create Corporate Synergies, Harvard Business School Press, Boston, 2006. 
Lal Rajiv, Bell David E., Salmon Walter J., Globalization of Retailing, John A. Quelch, Deshpandé Rohit (ed.) The Global Market: Developing a Strategy to Manage Across Borders, Jossey-Bass, San Francisco, 2004.

Lambin Jean-Jacques, Market-Driven Management, McGraw-Hill, London, 2000.

Lambin Jean-Jacques, Brondoni Silvio M., Ouverture de 'Market-Driven Management', Symphonya. Emerging Issues in Management(symphonya.unimib.it) , n. 1, 2000-2001. http://dx.doi.org/10.4468/2001.1.01ouverture

Lapoule Paul, Carrefour and Its Competitors in India, Management Decision, vol. 48, n. 3, 2010. http://dx.doi.org/10.1108/00251741011037765

Myers Hayley, Alexander Nicholas, The Role of Retail Internationalisation in the Establishment of an European Retail Structure, International Journal of Retail \& Distribution Management, vol. 35, n. 1, 2007. http://dx.doi.org/10.1108/09590550710722314

Mintzber Henry, Rebuilding Companies as Communities, Harvard Business Review, vol. 11, n. 4, 2009.

Odiorne George S., Measuring the Unmeasurable: Setting Standards for Measuring Performance, Business Horizon, vol. 30, n. 4, 1987. http://dx.doi.org/10.1016/0007-6813(87)90068-1

Papakiriakopoulos Dimitris, Pramatari Katerina, Collaborative Performance Measurement in Supply Chain, Industrial Management \& Data Systems, vol. 110, n. 9, 2010.

http://dx.doi.org/10.1108/02635571011087400

Park Cheol, Complaints of Asian Shoppers Toward Global Retailer: a Content Analysis of Ecomplaining to Carrefour Korea, Asia Pacific Journal of Marketing and Logistic, vol. 17, n. 3, 2005. http://dx.doi.org/10.1108/13555850510672368

Park Youngsun, Sternquist Brenda, The Global Retailer's Strategic Proposition and Choice of Entry Mode, International Journal of Retail \& Distribution Management, vol. 36, n. 4, 2008. http://dx.doi.org/10.1108/09590550810862688

Pieterse Nederveen J., Globalization and Culture: Global Mélange, Rowman \& Littlefield, California, 2009.

Quelch John A., Deshpandé Rohit, The Global Market: Developing a Strategy to Manage Across Borders, Jossey-Bass, San Francisco, 2004.

Raman Ananth, Watson Noel, Managing Global Supply Chains, John A. Quelch, Deshpandé Rohit (ed.), The Global Market: Developing a Strategy to Manage Across Borders, Jossey-Bass, San Francisco, 2004.

Salvioni Daniela M., Corporate Governance, Management Control and Global Competition, Symphonya. Emerging Issues in Management (symphonya.unimib.it), n. 1, 2005. http://dx.doi.org/10.4468/2005.1.03salvioni

Salvioni Daniela M., Market-Driven Management and Corporate Governance, Symphonya. Emerging Issues in Management (symphonya.unimib.it), n. 2, 2008. http://dx.doi.org/10.4468/2008.2.02salvioni

Svensson Göran, 'Glocalization' of Business Activities: a 'Glocal Strategy' Approach, Management Decision, vol. 39, n. 1, 2001. http://dx.doi.org/10.1108/EUM0000000005403

Webster Frederick E., Market-Driven Management, John Wiley \& Sons, New York, 2002. 


\section{Notes}

${ }^{1}$ Day G.S., The Market-Driven Organization, The Free Press, New York, 1999; Lambin J.J., MarketDriven Management, McGraw-Hill, London, 2000; Lambin J.J., Brondoni S.M., Ouverture de 'MarketDriven Management', Symphonya. Emerging Issues in Management (symphonya.unimib.it), n. 1, 20002001; Webster F.E., Market-Driven Management, John Wiley \& Sons, 2002, New York; Best R.J., Market-Based Management. Strategies for Growing Customer Value and Profitability, Prentice Hall, New Jersey, 2008; Brondoni S.M., Market Driven Management, Competitive Customer Value and Global Network, Symphonya. Emerging Issues in Management Symphonya. Emerging Issues in Management (symphonya.unimib.it), n. 1, 2009.

${ }^{2}$ The Internal Control Integrated Framework is the international reference model to harmonise internal controls. It was issued in the early 1990s by the Committee of Sponsoring Organisations of the Treadway Commission. Over the years, individual countries have used this Report as a reference model to elaborate internal control systems contained in self-governing documents. Cf. Committee of Sponsoring Organizations 2002, Internal Control. Integrated Framework, AICPA, USA.

${ }^{3}$ Pieterse N.J., Globalization and Culture: Global Mélange, Rowman \& Littlefield, California, 2009.

${ }^{4}$ According to the type of relationship, the form of integration can be easily linked to the followed types: legal when, faced with a single corporate entity, the operating activity is performed by selling points with different degrees of managerial autonomy (retail chains); operative, when a number of legally distinct companies voluntarily group together to integrate a number of operating functions (purchasing groups and voluntary unions); contractual, when legally autonomous companies draft a contract with mutual obligations, generating a relationship of economic and operational collaboration (for example, franchising, category management and private label contracts). The degree of risk sharing clearly differs according to the form chosen.

${ }^{5}$ Gatignon H., Kimberly J.R., Gunther R.E. 2004, Alliance on Globalizing, Cambridge University Press, UK; Clarke T., Dela Rama M. 2006, Corporate Governance and Globalization, The Governance of Globalization, Vol. 3, Sage Pub., USA; Freeman E.R. 2010, Strategic Management A Stakeholder Approach, Cambridge University Press, UK.

${ }^{6}$ In general, three levels of decision-making powers can be identified in complex retail companies: the first level contemplates broad decision-making autonomy and it drafts the organisation's strategic guidelines; the second level, with strongly differentiated decision-making autonomy, controls critical and/or supporting activities and may be permanent or provisional; the third level which is also characterised by different degrees of decision-making autonomy, is responsible for the final supply of the retail service in the territory.

7 Matrix-based structures are particularly appropriate for companies whose products are characterised by interdependence, shared knowledge and complementarity of resources between the various products/services.

${ }^{8}$ Meyers H., Alexander N. 2007, The Role of Retail Internationalisation in the Establishment of an European Retail Structure, International Journal of Retail \& Distribution Management, vol. 35, n. 1.

${ }^{9}$ Itami H., Roehl T.W. 1991, Mobilizing Invisible Assets, Softcover University Press, Harvard; Kaplan R.S., Norton D.P. 2004, Measuring the Strategic Readiness of Intangible Assets, Harvard Business Review, 82, 2; Kaplan R.S., Norton D.P. 2006, Alignment: Using the Balanced Scorecard to Create Corporate Synergies, Harvard Business School Press, Boston.

${ }^{10}$ Committee of Sponsoring Organizations 2002, cit. 